\title{
Developing a Continuous Flow-Square Wave Voltammetry Method for Determination of Atrazine in Soil Solutions Using the Hanging Mercury Drop Electrode
}

\author{
Luciana B. O. dos Santos, * Gilberto Abate and Jorge C. Masini \\ Instituto de Química, Universidade de São Paulo, CP 26077, 05513-970 São Paulo-SP, Brazil
}

\begin{abstract}
Este trabalho descreve o desenvolvimento de uma metodologia para a determinação de atrazina em solução de solo, utilizando Voltametria de Onda Quadrada em condições de Fluxo Contínuo, empregando o eletrodo de gota pendente de mercúrio. Para uma frequiência de $350 \mathrm{~Hz}$ e vazão de

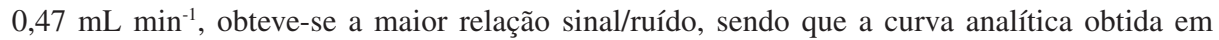
solução de solo na presença de tampão BR $40 \mathrm{mmol} \mathrm{L}^{-1}$ e $\mathrm{NaNO}_{3} 0,25 \mathrm{~mol} \mathrm{~L}^{-1}$ apresentou faixa linear entre 0,10 e $2,0 \mu \mathrm{g} \mathrm{mL}{ }^{-1}$, com limites de detecção e quantificação de 0,030 e $0,10 \mu \mathrm{g} \mathrm{mL}^{-1}$, respectivamente. A metodologia proposta proporcionou significativo aumento da velocidade analítica em comparação à metodologia em batelada, além de proporcionar baixo consumo de amostra, sendo possível determinar 72 amostras por hora consumindo apenas $341 \mu \mathrm{L}$ por análise. Os resultados foram similares aos obtidos por HPLC, mas o método proposto tem menor tempo de análise e não emprega solventes orgânicos.
\end{abstract}

This work describes the development of a Continuous Flow-Square Wave Voltammetry method for determination of atrazine using the hanging mercury drop electrode. The best signal to noise ratio was obtained at the square wave frequency of $350 \mathrm{~Hz}$ and flow rate of $0.47 \mathrm{~mL} \mathrm{~min}^{-1}$. Under these conditions, the analytical curve obtained in $0.010 \mathrm{~mol} \mathrm{~L}^{-1} \mathrm{CaCl}_{2}$ soil extracts in presence of $40 \mathrm{mmol} \mathrm{L}$ ${ }^{1} \mathrm{BR}$ buffer and $0.25 \mathrm{~mol} \mathrm{~L}^{-1} \mathrm{NaNO}_{3}$ was linear for atrazine concentrations between 0.10 and $2.0 \mu \mathrm{g}$ $\mathrm{mL}^{-1}$, with detection and quantification limits of 0.030 and $0.10 \mu \mathrm{g} \mathrm{mL}^{-1}$, respectively. The proposed method increased the analytical throughput in comparison with the batch methodology, allowing a sampling frequency of $72 \mathrm{~h}^{-1}$ to be accomplished. Besides, the sample consumption is significantly reduced, and only $341 \mu \mathrm{L}$ are necessary for each analysis. The results obtained were similar to the ones obtained by HPLC, but the proposed method is faster and does not use organic solvents.

Keywords: continuous flow, atrazine, soil solution, square wave voltametry

\section{Introduction}

The use of pesticides has increased in the world because of the increasing food production. Brazil occupies the $5^{\text {th }}$ position in the ranking of the countries with the largest consumption of these chemicals. Despite of this fact, monitoring of pesticide residues in soils and waters is not frequent in the country. ${ }^{1}$

Triazines have been used in several crops as pre and post emergence herbicides. Nowadays, atrazine and simazine are the most used triazines around the world. ${ }^{2-4}$ Significant amounts of atrazine may be stored in soil after application. The amount and persistence of the herbicide bound to soil particles is dependent on many factors. These include the type of soil, percent of organic matter, amount of clay, soil $\mathrm{pH}$, and soil structure. ${ }^{5}$ Walker ${ }^{6}$ showed that

* e-mail: 1bagdeve@usp.br atrazine adsorption is directly related to the concentration organic matter and humidity of soils.

A significant amount of atrazine may also be lost to surface runoff and into the groundwater via leaching from agricultural land. ${ }^{5}$ In USA and Europe, atrazine has been found in natural waters at concentrations higher than the Maximum Concentration Level (MCL), which is the maximum permissible pesticide concentration allowed in a public water source. In the USA the MCL for atrazine in drinking water is $3.0 \mu \mathrm{g} \mathrm{L}^{-1} .1,7$ In Europe the maximum individual concentration is $0.1 \mu \mathrm{g} \mathrm{L}^{-1}$, but the maximum concentration of all pesticide residues cannot exceed $0.5 \mu \mathrm{g}$ $\mathrm{L}^{-1}$. In Germany, the use of atrazine has been forbidden since 1991 because of the high concentrations that had been found in natural waters. ${ }^{1}$ In Brazil, the MCL for atrazine is $2.0 \mu \mathrm{g}$ $\mathrm{L}^{-1}{ }^{8}$ The half-life of triazines in soils can change from 1.5 months to 5 years, depending on degradation rates, which are strongly influenced by light and microorganisms living 
in soils. Deethylatrazine, a degradation product of atrazine, has similar toxicity to the parent compound, but interacts much more weakly with soils and soil components, being easily leached to surface and ground waters. $5,9,10$

Because chromatographic methods based on GC or HPLC are very sensitive and allow the separation of analogous compounds to be accomplished, they have been used for determination of atrazine and its metabolites in environmental samples. ${ }^{11-13}$ However, these methods use sophisticated instruments, as well toxic and high cost organic solvents, generating significant amounts mobile phase residues. In comparison with chromatography, electroanalytical techniques are faster and the instruments are less expensive, although individual determination of mixture components is not so straightforward as in chromatographic methods. Electroanalytical techniques have been developed and applied for determination of herbicides in waters, soils and food. ${ }^{14-19}$ De Souza et al. ${ }^{14}$ determined paraquat in natural water and commercial tea samples using gold electrodes obtained from recordable compact disc using square wave voltammetry (SWV). Massaropi et al. ${ }^{15}$ described the determination of picloram in natural waters using SWV and the hanging mercury drop electrode (HMDE). Determination of triazines in hemodialysis saline solutions by adsorptive stripping voltammetry onto the HMDE after extraction in acetonitrile was reported by Nascimento et al. ${ }^{19}$ Electroanalytical determination of atrazine with the HMDE has been reported in natural waters using differential pulse voltammetry ${ }^{16}$ and square wave voltammetry in stationary ${ }^{17}$ and flow conditions. ${ }^{18}$ The atrazine molecule exhibits two two-electron reduction processes in acidic medium, in which the preceding protonation takes place $(\mathrm{pK} 1.44)$. At $\mathrm{pH}<2$ the reduction process is diffusion controlled, while at $\mathrm{pH}$ between 2 and 4 the reduction current is kinetically controlled by the protonation. At higher $\mathrm{pH}$ atrazine is not electroactive. ${ }^{20}$

The Square Wave Voltammetry (SWV) is a pulse technique that offers the advantage of great speed and sensitivity. The excitation signal in SWV is obtained applying a series of forward and reverse pulses superimposed onto a constant height staircase of potential to the working electrode. The current is sampled twice in each wave cycle: once at end of the forward pulse and once at the end of the reverse pulse. The signal is given by the difference between these two currents. ${ }^{21-23}$ This paper describes the development and optimization of a continuous flow-square wave voltammetry (CF-SWV) for determination of atrazine in soil solutions using the hanging mercury drop electrode.

\section{Experimental}

\section{Apparatus and reagents}

Voltammetric measurements were carried out using an EG\&G PAR model 263A potentiostat. An EG\&G PAR model 303A Static Mercury Drop Electrode (SMDE) was used in all experiments. The flow cell adapted to the $\mathrm{Hg}$ capillary was already described in the literature. ${ }^{24}$ The electrochemical cell was completed with an $\mathrm{Ag} / \mathrm{AgCl}$ reference electrode ( $\mathrm{KCl}$ saturated) and a platinum auxiliary electrode. Ultrapure $\mathrm{N}_{2}\left(\mathrm{O}_{2}<2 \mathrm{ppm}\right)$ was used to remove dissolved $\mathrm{O}_{2}$ from the solutions and to provide an inert atmosphere inside the cell. Purified and doubly distilled mercury was used in the working electrode.

Solutions were driven to the electrochemical flow cell using an Alitea XV peristaltic pump fitted out with Pharmed ${ }^{\circledast}$ pump tubing of $0.8 \mathrm{~mm}$ i.d. All other connections were made of $0.8 \mathrm{~mm}$ i.d. polytetrafluoroethylene (PTFE) tubing. The flow channel from the sampling tube to the electrochemical cell was $40 \mathrm{~cm}$ long, including the pump tubing.

All $\mathrm{pH}$ measurements were performed with a Metrohm $654 \mathrm{pH}$ meter (precision of $0.001 \mathrm{pH}$ units) fitted out to an Ingold $\mathrm{HA} 405-60-8 \mathrm{~b}-\mathrm{S} 7 / 20 \mathrm{Ag} / \mathrm{AgCl}$ combination glass electrode.

An LC 9A Shimadzu high performance liquid chromatograph (HPLC), equipped with a SPD 6 AV UV detector, and the LC Workstation Class-LC 10 software was used in all experiments for quantification of atrazine. A SB C-18 Zorbax - HP column ( $3.5 \mu \mathrm{m}, 150$ x $4.6 \mathrm{~mm})$ connected to a C-18 Phenomenex guard column was used. Sample injection was made with a rotary Rheodyne valve using a $20 \mu \mathrm{L}$ sample loop.

All reagents used in this work were of analytical grade, prepared in deionized water (Simplicity 185 system from Millipore coupled to an UV lamp). A stock $20 \mu \mathrm{g} \mathrm{mL}^{-1}$ atrazine (AT) was prepared dissolving the solid standard (Riedel-de Haën, purity $>99 \%$, molar mass of $215.69 \mathrm{~g} \mathrm{~mol}^{-1}$ ) in deionized water. Working solutions were prepared either in deionized water or in blank soil extracts, with all the final solutions being prepared in presence of $40 \mathrm{mmol} \mathrm{L}^{-1}$ Britton Robinson (BR) buffer and $0.25 \mathrm{~mol} \mathrm{~L}^{-1} \mathrm{NaNO}_{3}$ at $\mathrm{pH}$ 2.0. The BR buffer was prepared from a mixture of phosphoric acid $\left(\mathrm{p} K_{\mathrm{a}} 2.14,7.20\right.$ and 12.15), acetic acid $\left(\mathrm{p} K_{\mathrm{a}} 4.75\right)$ and boric acid $\left(\mathrm{p}_{\mathrm{a}} 9.24,12.74\right.$ and 13.80), with all components at concentration of $40 \mathrm{mmol} \mathrm{L}^{-1}$. The $\mathrm{pH}$ of the BR buffer was monitored with combination glass electrode and adjusted to 2.0 by adding $\mathrm{NaOH}$ solution. 


\section{Soil sample}

The soil sample was collected at the experimental farm of the Escola Superior de Agricultura Luiz de Queiroz da Universidade de São Paulo (ESALQ-USP) in the Piracicaba municipality, São Paulo state, Brazil, in a $500 \mathrm{~m}^{2}$ area with no history of application of herbicides. Fifteen surface samples were collected at depths between 0 and $20 \mathrm{~cm}$ from four different points and mixed to form a composed sample. The soil was air-dried and gently ground with a pestle and mortar to pass in a $1.0 \mathrm{~mm}$ sieve. The sieved sample was further dried in a vacuum oven at $35{ }^{\circ} \mathrm{C}$ until constant weight, a process that required approximately 48 $\mathrm{h}$, and finally stored in a desiccator. The $\mathrm{CHN}$ composition was: $1.58 \pm 0.04 \% \mathrm{C} ; 0.76 \pm 0.04 \% \mathrm{H} ; 0.07 \pm 0.01 \% \mathrm{~N}$. Sand, silt and clay contents were 29, 18 and 53\%, respectively.

\section{Obtaining soil solutions in $0.010 \mathrm{~mol} \mathrm{~L}^{-1} \mathrm{CaCl}_{2}$}

To improve centrifugation efficiency of soil suspensions, as well as to minimize cation exchange, the soil solutions were obtained in $0.010 \mathrm{~mol} \mathrm{~L}^{-1} \mathrm{CaCl}_{2}$, as recommended by the OECD guideline 106 to perform adsorption-desorption of chemicals to soils using the batch equilibrium approach. ${ }^{25}$ A mass of $1.000 \mathrm{~g}( \pm 1 \mathrm{mg})$ of the dried soil was transferred to polypropylene centrifuge tubes (Corning) with capacity of $10 \mathrm{~mL}$. A volume of 50 $\mu \mathrm{L}$ of $1.0 \mathrm{~mol} \mathrm{~L}^{-1} \mathrm{CaCl}_{2}$ was added to each tube, followed by a suitable volume of a $20 \mu \mathrm{g} \mathrm{mL}^{-1}\left(92.7 \mu \mathrm{mol} \mathrm{L} \mathrm{L}^{-1}\right)$ atrazine stock solution to provide initial atrazine concentrations of $0,0.25,0.50,1.00,2.00,4.00,8.00$ and $12.0 \mu \mathrm{g} \mathrm{mL}^{-1}$ after completing the total solution volume to $5.00 \mathrm{~mL}$ with deionized water. All centrifuge tubes were sealed, protected from light and shaken in a thermostated orbital shaker for $24 \mathrm{~h}$ at $25.0 \pm 0.1{ }^{\circ} \mathrm{C}$. The contact time of $24 \mathrm{~h}$ was previously determined to allow the system to reach the chemical equilibrium. ${ }^{9,26}$ After equilibration the solid phases were let to decant and the supernatant solution was filtered through $0.45 \mu \mathrm{m}$ cellulose acetate membranes. A volume of $2.00 \mathrm{~mL}$ of this solution was pipetted and properly conditioned for square wave voltammetry measurements by adding $2.00 \mathrm{~mL}$ of $80 \mathrm{mmol} \mathrm{L}^{-1} \mathrm{BR}$ buffer ( $\mathrm{pH} 2.0$ ) in $0.50 \mathrm{~mol} \mathrm{~L}-1 \mathrm{NaNO}_{3}$.

\section{Standards in blank soil solutions}

To correct for matrix effects, calibration of the system was made in soil extracts prepared in the same medium used to perform the spike experiments. To prepare the standard solutions in the matrix solution, a mass of $10.0 \mathrm{~g}$ of soil was equilibrated with $49.50 \mathrm{~mL}$ of deionized water plus $0.50 \mathrm{~mL}$ of $1.0 \mathrm{~mol} \mathrm{~L}{ }^{-1} \mathrm{CaCl}_{2}$. This extraction was performed for $24 \mathrm{~h}$ in a thermostated orbital shaker programmed at $25.0 \pm 0.1^{\circ} \mathrm{C}$. After extraction, the solid phases were let to decant and the supernatant solution was filtered through $0.45 \mu \mathrm{m}$ cellulose acetate membranes. Standard solutions of atrazine with concentrations 0.010 , $0.060,0.10,0.25,0.50,1.0$ and $2.0 \mu \mathrm{g} \mathrm{mL}^{-1}$ were prepared by diluting suitable volumes of a $10.0 \mu \mathrm{g} \mathrm{mL}^{-1}$ stock atrazine solution (prepared in $80 \mathrm{mmol} \mathrm{L}^{-1} \mathrm{BR}$ buffer and $0.50 \mathrm{~mol}$ $\mathrm{L}^{-1} \mathrm{NaNO}_{3}$ ) in $2.50 \mathrm{~mL}$ of the filtered soil extract, completing to $5.00 \mathrm{~mL}$ with appropriate volumes of 80 mmol L-1 BR buffer in $0.50 \mathrm{~mol} \mathrm{~L}^{-1} \mathrm{NaNO}_{3}$. For comparison, another set of standard solutions was prepared in the 40 mmol L-1 BR buffer (pH 2.0) in $0.25 \mathrm{~mol} \mathrm{~L}^{-1} \mathrm{NaNO}_{3}$ using only deionized water.

\section{Procedure of analysis}

After degassing with $\mathrm{N}_{2}$, the solution is pumped at a flow rate of $0.47 \mathrm{~mL} \mathrm{~min}^{-1}$ toward the flow cell. The potentiostat is programmed with a delay time of $40 \mathrm{~s}$ of open circuit to allow the sample solution to fill the tubing and the flow cell, flushing the system from the solution used in the previous analysis. Next, the mercury drop is changed and, after an equilibrium time of $5 \mathrm{~s}$ the potential is swept from -0.5 to $1.2 \mathrm{~V}$ at a frequency of $350 \mathrm{~Hz}$ and pulse height of $25 \mathrm{mV}$.

\section{HPLC analysis}

The HPLC analyses were carried out using an isocratic elution mode with a mobile phase constituted by $50 \%$

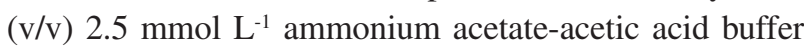
(pH 4.5) and 50\% (v/v) acetonitrile. Both solutions constituting the mobile phase were previously filtered through $0.45 \mu \mathrm{m}$ PTFE membranes. Helium was used as degassing gas in all experiments. The analyses were

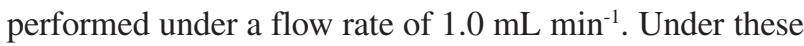
analytical conditions, the atrazine retention time is close to $4.2 \mathrm{~min}$. The UV detector monitored the absorbance at $220 \mathrm{~nm}^{.17}$

\section{Results and Discussion}

Initially, the amperometric determination of atrazine was investigated in a flow injection system using the 40 mmol L-1 BR buffer at $\mathrm{pH} 2.0$ as carrier. The readouts obtained for five injections of $200 \mu \mathrm{L}$ of $10 \mu \mathrm{g} \mathrm{mL}^{-1}$ atrazine solution (Figure 1) reveals that amperometric detection is not suitable using a single mercury drop because the electrode is clearly passivated by atrazine adsorption, causing a systematic decrease of peak currents after each sample injection. Changing the 


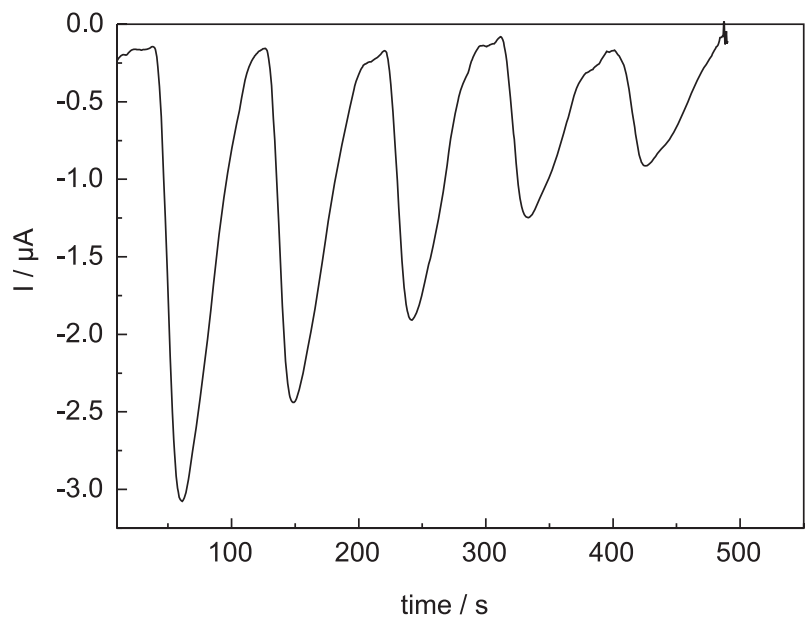

Figure 1. Amperometric readouts in a flow injection system. Sample volume and concentration $=200 \mu \mathrm{L}$ of $10.0 \mu \mathrm{g} \mathrm{mL}^{-1}$ atrazine solution prepared in the carrier solution. Carrier composition $=40 \mathrm{mmol} \mathrm{L}^{-1} \mathrm{BR}$ buffer at $\mathrm{pH} 2.0$ in medium of $0.25 \mathrm{~mol} \mathrm{~L}^{-1} \mathrm{NaNO}_{3}$. Flow rate $=0.47 \mathrm{~mL}$ $\min ^{-1}$. Applied potential $=-1.15 \mathrm{~V}$ vs $\mathrm{Ag} / \mathrm{AgCl}$.

mercury drop would circumvent this drawback of the amperometric detection, but at the cost of an additional time for current stabilization before a new sample could be injected. Thus, we opted for a pulse technique (square wave voltammetry) using a fresh $\mathrm{Hg}$ drop for each sample, under continuous flow operation. For optimization of the proposed methodology, the following parameters were studied: concentration of supporting electrolyte $\left(\mathrm{NaNO}_{3}\right)$, radius of the $\mathrm{Hg}$ drop, flow rate during the potential sweep and frequency of square wave.

\section{Concentration of supporting electrolyte and $\mathrm{Hg}$ drop radius}

A $10 \mu \mathrm{g} \mathrm{mL}^{-1}$ atrazine working solution in $40 \mathrm{mmol}$ $\mathrm{L}^{-1} \mathrm{BR}$ buffer at $\mathrm{pH} 2.0$ was studied in presence of 0.050 , $0.10,0.25$, and $0.50 \mathrm{~mol} \mathrm{~L}^{-1} \mathrm{NaNO}_{3}$. These experiments were performed using a frequency of $60 \mathrm{~Hz}$, flow rate of $2.70 \mathrm{~mL} \mathrm{~min}{ }^{-1}$ and $\mathrm{Hg}$ drop radius of $0.46 \mathrm{~mm}$. Voltammograms with significant variation of base line and strong influence of peristaltic pump pulsation were obtained in supporting electrolyte concentrations of 0.050 and $0.10 \mathrm{~mol} \mathrm{~L}^{-1}$. The repeatability of the voltammograms, as well as their stability, were improved in medium of 0.25 or $0.50 \mathrm{~mol} \mathrm{~L}^{-1} \mathrm{NaNO}_{3}$, with less influence of the peristaltic pump movements. High frequencies used in square wave voltammetry require high concentrations of supporting electrolytes to speed up the decay of the capacitive current, minimizing its interference and improving signal stability. Additionally, we have noticed that a high concentration of supporting electrolyte is especially important in continuous flow conditions using the proposed flow cell with the HMDE. High concentration of electrolyte imply in high electrical conductivity, which is very important to maintain the electric contact between the working electrode inside the flow cell cavity and the external solution in which the auxiliary and reference electrodes are immersed. The best repeatability of peak currents for the $10 \mu \mathrm{g} \mathrm{mL}^{-1}$ atrazine solution was obtained in $0.25 \mathrm{~mol} \mathrm{~L}^{-1} \mathrm{NaNO}_{3}$, so that this concentration was used in the further studies.

Studying drop radius of $0.29,0.37$ and $0.46 \mathrm{~mm}$, it was verified that the peak currents increasead linearly with the surface area, indicating that the flow cell geometry allows the mercury drop surface to be fully exposed to the sample solution flowing through the cell. The better signal to noise ratio was observed for a mercury drop radius of $0.46 \mathrm{~mm}$, so that this drop size was chosen to perform atrazine quantification.

\section{Optimization of frequency of square wave and flow rate}

Reduction of atrazine, studied by direct current polarography or differential pulse voltammetry, has been reported as fully irreversible. ${ }^{16,20} \mathrm{In}$ a previous work using square wave voltammetry and the hanging mercury electrode in stationary solution, we noticed a significant contribution of anodic component in the reverse current, suggesting that at frequencies between 300 and $400 \mathrm{~Hz}$ the atrazine reduction has a behavior, at least, partially reversible. ${ }^{17}$ Such a behavior was confirmed in the present work under continuous flow conditions, as evidenced in Figure 2, which shows the direct, reverse and net currents for atrazine reduction obtained at 200 and $300 \mathrm{~Hz}$. These experiments were performed using a $0.50 \mu \mathrm{g} \mathrm{mL}^{-1}$ atrazine solution in $40 \mathrm{mmol} \mathrm{L}^{-1} \mathrm{BR}$ buffer ( $\mathrm{pH} 2.0$ ) and $0.25 \mathrm{~mol}$ $\mathrm{L}^{-1} \mathrm{NaNO}_{3}$. At the frequency of $300 \mathrm{~Hz}$ the peak current is the difference between cathodic and anodic currents, leading to an enhanced net current that improves the sensitivity and detectability. The experiments were also performed with a $2.0 \mu \mathrm{g} \mathrm{mL}^{-1}$ atrazine solution in the soil solution conditioned with the BR buffer and supporting electrolyte. Independently of the flow rate and medium utilized, the highest values of peak current were observed at $350 \mathrm{~Hz}$ (Figure 3). From the square wave theory, ${ }^{21-23}$ a direct and linear relation between frequency and peak current should be expected. The decrease of peak currents at larger frequencies may be related to the coupling effects of electrode kinetics with the mass transport under continuous flow, which does not occur at stationary electrodes, as pointed out by Brett et al. ${ }^{27}$

Figure 4 shows the influence of the flow rate on the peak currents for reduction of atrazine at the mercury electrode. 

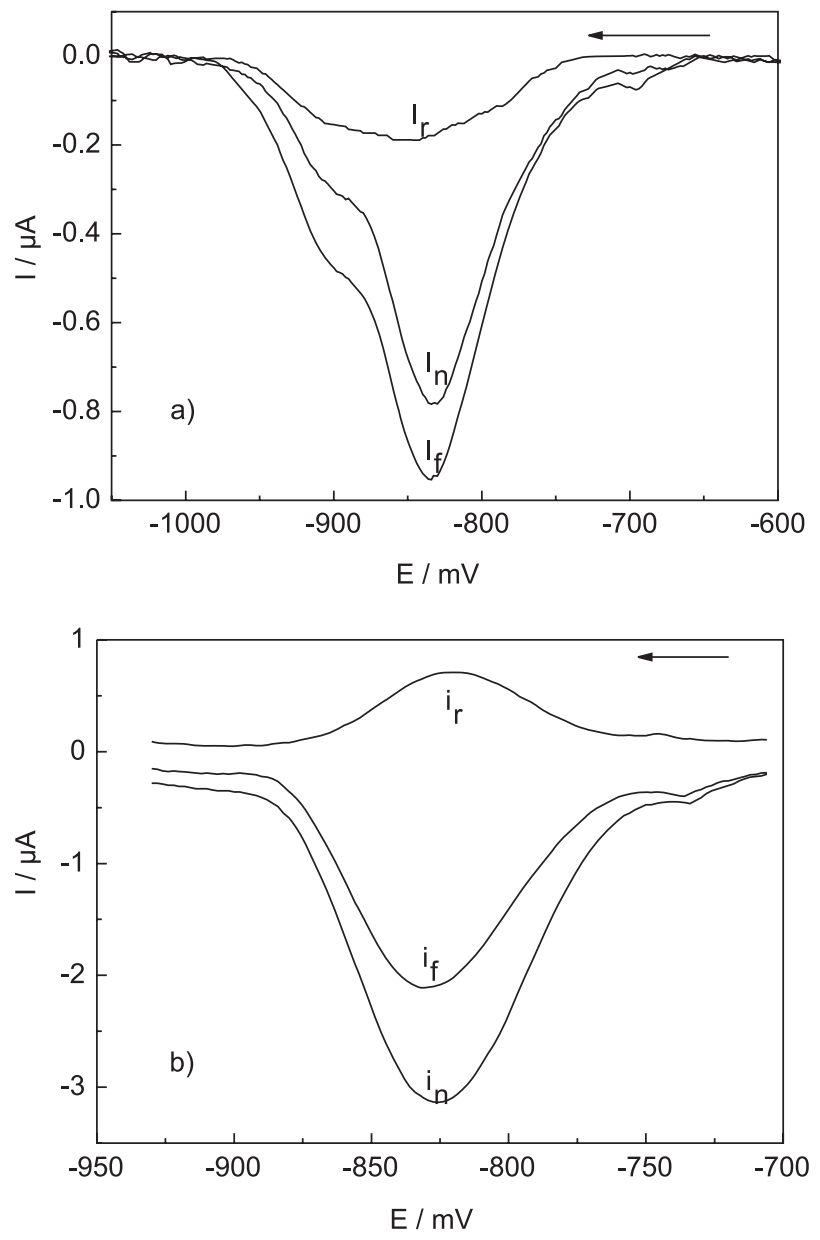

Figure 2. Comparison of the forward $\left(i_{f}\right)$, reverse $\left(i_{r}\right)$ and net $\left(i_{n}\right)$ currents of continuous flow square wave voltammograms obtained for a $0.50 \mu \mathrm{g} \mathrm{mL}^{-1}$ atrazine solution in $40 \mu \mathrm{mol} \mathrm{L}^{-1} \mathrm{BR}$ buffer at $\mathrm{pH} 2.0$ in medium of $0.25 \mathrm{~mol} \mathrm{~L}^{-1} \mathrm{NaNO}_{3}$. The voltammograms were obtained at frequencies of 200 (a) and 300 (b) Hz. The arrow indicates the direction of the potential scan.

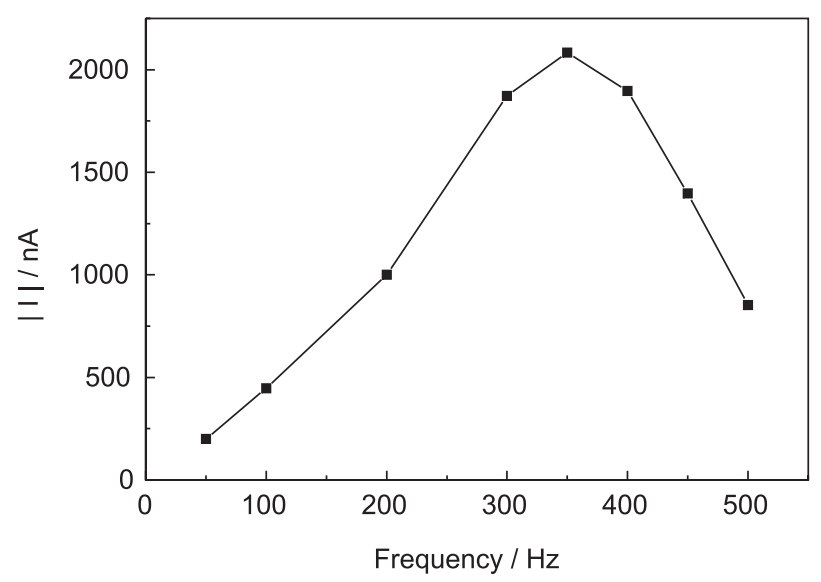

Figure 3. Effect of the square wave frequency on the peak currents of a $2.0 \mu \mathrm{g} \mathrm{mL}^{-1}$ atrazine solution in $40 \mathrm{mmol} \mathrm{L}^{-1} \mathrm{BR}$ buffer (pH 2.0) and 0.25 mol L ${ }^{-1} \mathrm{NaNO}_{3}$ prepared in soil solution. Flow rate $=0.47 \mathrm{~mL} \mathrm{~min}^{-1}$.
In the solutions of $40 \mathrm{mmol} \mathrm{L}{ }^{-1} \mathrm{BR}$ buffer and $0.25 \mathrm{~mol} \mathrm{~L}^{-1}$ $\mathrm{NaNO}_{3}$ prepared in deionized water (no blank soil solution present), the peak current in flowing solution is higher than with a quiescent solution inside the flow cell, as obtained in the condition in which the flow is stopped during the potential sweep. Increase in the flow rate causes an increase in the peak currents, which is explained by the enhanced mass transport from bulk solution to the surface of mercury. At higher flow rates the thickness of the diffusion layer decreases and a larger number of molecules can suffer electron transfer reactions at the electrode surface, increasing the magnitude of the measurement. However, when the experiments were performed in soil solutions the situation was reversed (Figure 4), and the peak currents decreased systematically with the increase in the flow rate. Such a behavior may be related to either slow dissociation kinetics of products formed between atrazine and soil components, or poisoning of the electrode by these components.

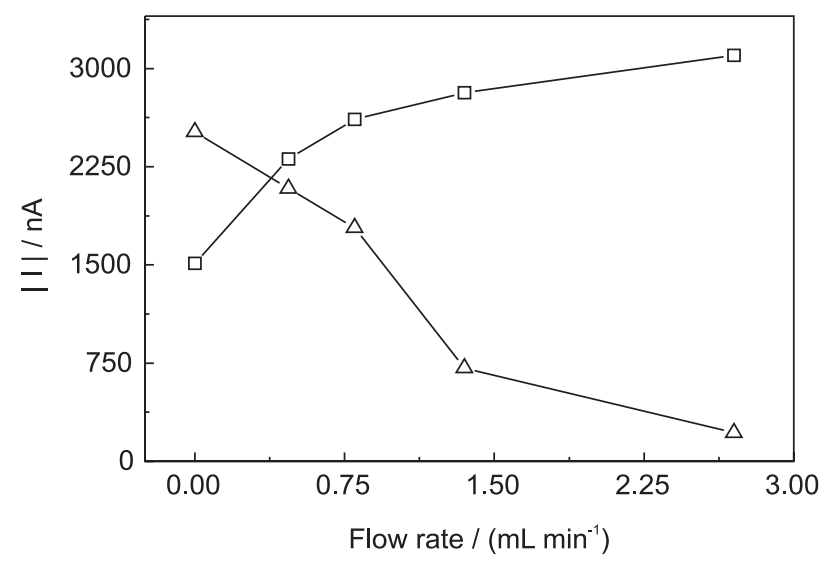

Figure 4. Influence of flow rate on the peak currents of square voltammograms of a $2.0 \mu \mathrm{g} \mathrm{mL}^{-1}$ atrazine solution prepared in soil solution in $40 \mathrm{mmol} \mathrm{L}^{-1} \mathrm{BR}$ buffer and $0.25 \mathrm{~mol} \mathrm{~L}^{-1} \mathrm{NaNO}_{3}(\Delta)$; and $0.5 \mu \mathrm{g}$ $\mathrm{mL}^{-1}$ atrazine solution in $40 \mathrm{mmol} \mathrm{L}^{-1} \mathrm{BR}$ buffer and $0.25 \mathrm{~mol} \mathrm{~L}^{-1} \mathrm{NaNO}_{3}$ prepared in deionized water $(\square)$. Square wave frequency $=350 \mathrm{~Hz}$.

\section{Analytical curves}

Analytical curves were obtained using a square wave frequency of $350 \mathrm{~Hz}$ and flow rate of $0.47 \mathrm{~mL} \mathrm{~min}^{-1}$. For atrazine standard solutions prepared in $40 \mathrm{mmol} \mathrm{L}^{-1} \mathrm{BR}$ buffer and $0.25 \mathrm{~mol} \mathrm{~L}^{-1} \mathrm{NaNO}_{3}$ using only deionized water, the linear dynamic range was observed for concentrations between 0.01 and $0.25 \mu \mathrm{g} \mathrm{mL}^{-1}$, with the analytical curve fitting the equation:

ip $=(-5.2 \pm 0.1) \mathrm{C}_{\text {atrazine }}+(0.04 \pm 0.02)$

with $\mathrm{r}^{2}=0.998$ and the slope given in $\mu \mathrm{A} \mathrm{mL} \mu \mathrm{g}^{-1}$.

The detection and quantification limits were computed according to Miller and Miller, ${ }^{28}$ resulting the values of 0.010 and $0.025 \mu \mathrm{g} \mathrm{mL}^{-1}$, respectively. 
The analytical curve obtained in soil solution, in presence of $40 \mathrm{mmol} \mathrm{L}^{-1} \mathrm{BR}$ buffer and $0.25 \mathrm{~mol} \mathrm{~L}^{-1} \mathrm{NaNO}_{3}$, is shown in Figure 5, having a linear dynamic range between 0.10 and $2.0 \mu \mathrm{g} \mathrm{mL}^{-1}$, fitting to the linear equation:

ip $=(-0.66 \pm 0.01) \mathrm{C}_{\text {atrazine }}-(0.02 \pm 0.01)$

with $\mathrm{r}^{2}=0.999$. In this case the limits of detection and quantification were 0.030 and $0.10 \mu \mathrm{g} \mathrm{mL}^{-1}$, respectively. Because of the significant matrix effect, which decreased the sensitivity by a factor of 7.9, the standard solutions were prepared in $50 \%(\mathrm{v} / \mathrm{v})$ blank soil solutions prepared according to described in the experimental section. In the case of unknown soil samples, the method of standard addition has to be used for determination of atrazine in soil solution by the proposed CF-SWV method.

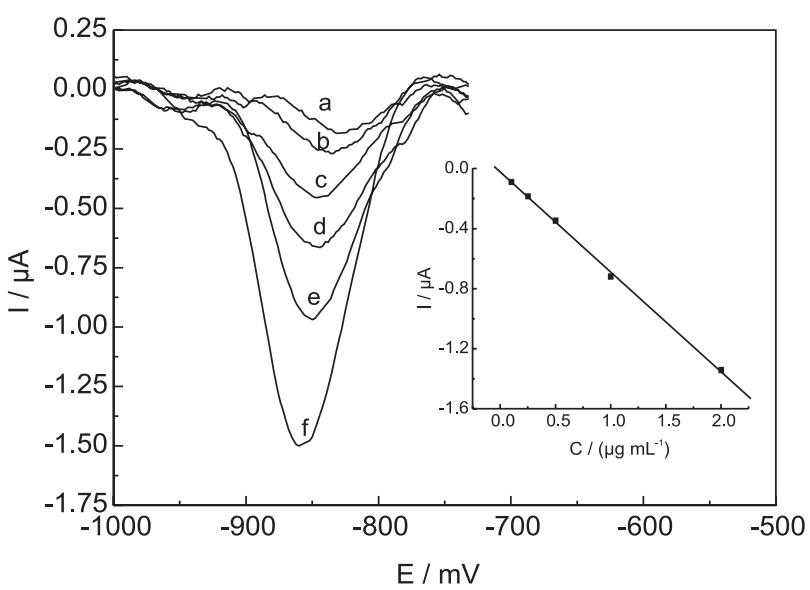

Figure 5. Analytical curve and continuous flow square wave voltammograms for atrazine obtained in soil solution conditioned with $40 \mathrm{mmol}$ $\mathrm{L}^{-1} \mathrm{BR}$ buffer ( $\mathrm{pH} 2.0$ ) and $0.25 \mathrm{~mol} \mathrm{~L}^{-1} \mathrm{NaNO}_{3}$. Flow rate $=0.47 \mathrm{~mL} \mathrm{~min}^{-1}$ and square wave frequency of $350 \mathrm{~Hz}$. Atrazine concentrations: 0 (a); 0.1 (b); 0.25 (c); 0.50 (d); 1.0 (e) and $2.0 \mu \mathrm{g} \mathrm{mL}-1$ (f).

\section{Interferences}

The influence of natural organic matter components, atrazine metabolites and other herbicides on the peak currents was studied, as shown in Table 1. Humic acid (isolated from vermicompost) did not cause significant interference, but fulvic acid (also isolated from vermicompost) depleted the peak current by a factor of about $21 \%$. The difference between humic and fulvic acid may be attributed to their solubility at $\mathrm{pH} 2.0$. At this $\mathrm{pH}$ humic acids predominantly precipitates, while the fulvic acid is soluble. Interference of fulvic acid may be explained by either, adsorption onto the electrode surface, or interaction with atrazine in solution. Similarly to other fulvic acids, ${ }^{29}$ the studied sample has a major contribution of carboxylic groups with pKa close to 2, which can interact electrostatically with protonated atrazine molecules at $\mathrm{pH}$ 2.0.
Table 1. Effect of possible interferents on peak current observed for an $0.10 \mu \mathrm{g} \mathrm{L}^{-1}$ atrazine solution prepared in $40 \mathrm{mmol} \mathrm{L}^{-1} \mathrm{BR}$ buffer at $\mathrm{pH} 2.0$ in medium of $0.25 \mathrm{~mol} \mathrm{~L}^{-1} \mathrm{NaNO}_{3}$. Experiments were performed in triplicate using a frequency of $350 \mathrm{~Hz}$, flow rate of $0.47 \mathrm{~mL} \mathrm{~min}^{-1}$

\begin{tabular}{lcc}
\hline Interferent & $\begin{array}{c}\text { Concentration/ } \\
\left(\mu \mathrm{g} \mathrm{mL}^{-1}\right)\end{array}$ & $\begin{array}{c}\text { Signal } \\
\text { variation/\% }\end{array}$ \\
\hline Humic acid & 5.0 & -1 \\
Fulvic acid & 5.0 & -21 \\
Desethylatrazine (DEA) & 0.1 & +48 \\
Deisopropylatrazine (DIA) & 0.1 & +53 \\
Hydroxyatrazine (AT-OH) & 0.1 & +4 \\
Dedialkylatrazine (DEDIA) & 0.1 & -4 \\
Propazine & 0.1 & +56 \\
Paraquat & 0.1 & -62 \\
Diquat & 0.1 & -27 \\
\hline
\end{tabular}

The atrazine metabolites DEA and DIA are potential interferents, enhancing the peak currents. Dedialkyatrazine and AT-OH did not cause significant interference under the experimental conditions. Propazine, another triazine herbicide, similarly to DEA and DIA, caused positive interference because it is reduced at potential very close to atrazine. Other herbicides such as paraquat and diquat caused a significant decrease in the peak currents, a fact that can be attributed to adsorption of these cationic species to the electrode surface.

Because the method is liable to several interferences and has a detection limit above the MCL values in waters, its application should be limited to the characterization of sorption kinetics and sorption isotherms of atrazine onto soils with no history of application of herbicides. Otherwise, the method should be implemented in the detection of HPLC systems.

Samples

Analyses of soil solutions obtained after spiking the soil with known amounts of atrazine were performed in triplicate by the proposed method and in duplicate by HPLC. The results are shown in Table 2 and were evaluated using the $t$ test for comparison between the means of two samples. ${ }^{28}$ For the $95 \%$ confidence level, the experimental $t$ values were smaller than the critical $t$ value of 3.18 for the present situation. These results indicate that there is no evidence of significant difference between the concentration means found by the two methods.

\section{Conclusions}

The use of the proposed CF-SWV method increased significantly the sampling throughput of atrazine analyses in comparison with the batch approach. Using a flow rate of $0.47 \mathrm{~mL} \mathrm{~min}^{-1}$ and square wave frequency of $350 \mathrm{~Hz}$, the time needed to flush the system and to perform one 
Table 2. Atrazine concentration values in $0.010 \mathrm{~mol} \mathrm{~L}^{-1} \mathrm{CaCl}_{2}$ soil solutions obtained by the proposed CF-SWV method and HPLC. The critical $t$ value at $95 \%$ confidence level and 3 degrees of freedom is $3.18^{22}$

\begin{tabular}{cccc}
\hline \multicolumn{4}{c}{ Method/Equilibrium Concentration } \\
\hline $\begin{array}{c}\text { Initial } \\
\begin{array}{c}\text { Concentration } / \\
\left(\mu \mathrm{g} \mathrm{mL}^{-1}\right)\end{array}\end{array}$ & $\begin{array}{c}\text { CF-SWV / } \\
\left(\mu \mathrm{g} \mathrm{mL}^{-1}\right)\end{array}$ & $\begin{array}{c}\text { HPLC } / \\
\left(\mu \mathrm{g} \mathrm{mL}^{-1}\right)\end{array}$ & $\begin{array}{c}\text { Experimental } \\
|\mathrm{t}|\end{array}$ \\
\hline 0.25 & $0.14 \pm 0.01$ & $0.144 \pm 0.004$ & 0.05 \\
0.50 & $0.288 \pm 0.004$ & $0.286 \pm 0.003$ & 0.32 \\
1.0 & $0.65 \pm 0.02$ & $0.665 \pm 0.001$ & 1.61 \\
2.0 & $1.29 \pm 0.02$ & $1.32 \pm 0.01$ & 1.58 \\
4.0 & $2.6 \pm 0.1^{\mathrm{a}}$ & $2.81 \pm 0.01$ & 2.81 \\
8.0 & $5.5 \pm 0.2^{\mathrm{a}}$ & $5.74 \pm 0.01$ & 1.97 \\
12.0 & $8.4 \pm 0.1^{\mathrm{a}}$ & $8.79 \pm 0.01$ & 2.80 \\
\hline
\end{tabular}

${ }^{a}$ Solutions were analyzed after proper dilution.

determination is $50 \mathrm{~s}$, implying that it is possible to perform 72 analyses per hour, consuming $341 \mu \mathrm{L}$ of sample per analysis. The CF-SWV readouts are strongly affected by matrix of soil components, so that samples have to be analyzed using matrix matching or standard addition approaches. The major advantages of the proposed CF-SWV over HPLC are the low consumption of reagent and the short time of analysis. In the HPLC method a consumption of $2.1 \mathrm{~mL}$ of acetonitrile per analysis can be estimated. Additionally, the HPLC method requires near $30 \mathrm{~min}$ of column conditioning before starting up the serial analyses, which requires approximately $15 \mathrm{~mL}$ of acetonitrile at the flow rate of $1.0 \mathrm{~mL} \mathrm{~min}^{-1}$. The CF-SWV method does not require conditioning and use of organic solvent. On the other hand, the HPLC method is more sensitive, having a detection limit of $0.8 \mu \mathrm{g} \mathrm{L}^{-1}\left(3.7 \times 10^{-9} \mathrm{~mol} \mathrm{~L}^{-1}\right)^{9}$ and can be calibrated with standards prepared in deionized water.

\section{Acknowledgments}

Authors are grateful to CNPq and FAPESP for financial support and fellowships. The authors are also grateful to Prof. Godofredo C. Vitti and Jonas D. Cuzzi (ESALQUSP) for helping with the soil sampling.

\section{References}

1. h t t p : / / w w w . c n p d i a. e m b r a p a. b r / menuleft_desenv_publicacoes_series_comunicado/ CT14_96.pdf, accessed in may 2005.

2. Townsend, M.A.; Young, D.P.; Int. J. Environ. Anal. Chem. 2000, 78, 9 .

3. Laabs, V.; Amelung, W.; Pinto, A.; Altstaedt, A.; Zech, W.; Chemosphere 2000, 41, 1441.

4. Shiptalo, M. J.; Owens, L.B.; Environ. Sci. Technol. 2003, 37, 944.

5. Graymore, M.; Stagnitti, F.; Allison, G.; Environ. Int. 2001, 26, 483.
6. Walker, A.; Pest. Sci. 1972, 3, 139.

7. Lesan, H.M.; Bhandari, A.; Water Res. 2003, 37, 1644.

8. http://www.mma.gov.br/port/conama/res/res05/res35705.pdf, accessed in may 2005.

9. Abate, G.; Penteado, C.J.; Cuzzi, J.D.; Vitti, G.C.; Masini, J.C.; J. Agric. Food Chem. 2004, 52, 6747.

10. Kolpin, D.W.; Thurman, E.M., Linhart, S.M.; Sci. Total Environ. 2000, 248, 115.

11. Sherma, J.; Anal. Chem. 1993, 65, 40R.

12. Barcelo, D.; J. Chromatogr. 1993, 643, 117.

13. Ahel, M.; Evans, K.M.; Fileman, T.W.; Mantoura, R.F.C. Anal. Chim. Acta 1992, 268, 195.

14. de Souza, D.; Codognoto, L.; Machado, S.A.S.; Avaca, L.A.; Anal. Lett. 2005, 38, 331.

15. Massaroppi, M.R.C.; Machado, S.A.S.; Avaca, L.A.; J. Braz. Chem. Soc. 2003, 14, 113.

16. Vaz, C.M.P.; Crestana, S.; Machado, S.A.S.; Mazo, L.H.; Avaca, L.A.; Int. J. Environ. Anal. Chem. 1996, 62, 65.

17. dos Santos, L.B.O.; Abate, Masini, G.; J.C.; Talanta 2004, 62, 667.

18. dos Santos, L.B.O; Silva, M.S.P.; Masini, J.C.; Anal. Chim. Acta 2005, 528, 21.

19. do Nascimento, P.C.; Bohrer, D.; de Carvalho, L.M.; Trevisan, J.; Pilau, E.J.; Vendrame, Z.B.; Dessuy, M.B.; J. Braz. Chem. Soc. 2003, 14, 577.

20. Pospisil, L.; Trskova, R.; Fuoco, R.; Colombini, M.P.; J. Electroanal. Chem. 1995, 395, 189.

21. O’Dea, J.J.; Osteryoung, J.; Osteryoung, R.A.; Anal. Chem. 1981, 53, 695.

22. Osteryoung, J.; O’Dea, J.J. in Electroanalytical Chemistry; A.J. Bard, ed.; Marcel Dekker: New York, 1986, vol. 14

23. de Souza, D.; Machado, S.A.S.; Avaca, L.A.; Quim. Nova, 2003, $26,81$.

24. Abate, G.; Lichtig, J.; Masini, J.C.; Talanta 2002, 58, 433.

25. Organisation for Economic Co-operation and Development (OECD) Guideline 106. OECD Guideline for the Testing of Chemicals. Adsorption-desorption using a batch equilibrium method. $21^{\text {st }}$ January 2000.

26. Fingler, S.; Stipicevic, S.; Drevenkar, V.; Int. J. Environ. Anal. Chem. 2004, 84, 83.

27. Brett, C.M.A.; Lima, J.L.F.C.; Garcia, M. B. Q.; Analyst 1994, 119, 1229.

28. Miller, J.C.; Miller, J.N.; Statistics for Analytical Chemistry, $2^{\text {th }}$ ed.; Ellis Horwood Ltd.: Chichester, 1988.

29. Leenheer, J.A.; Wershaw, R.L.; Reddy, M.M.; Environ. Sci. Technol. 1995, 29, 393.

Received: May 20, 2005

Published on the web: October 11, 2005

FAPESP helped in meeting the publication costs of this article. 